\title{
ECOLOGICAL KNOWLEDGE ABOUT PROTECTED AREAS IN THE EAST ZONE OF SÃO PAULO, SP: IMPLICATIONS FOR SUSTAINABILITY IN URBAN AREA
}

\author{
J. U. B. FRANÇA, A. P. N. LAMANO-FERREIRA, M. S. RUIZ, C. C. QUARESMA, C. T. KNIESS, H. R. RAMOS \\ and M. L. FERREIRA* \\ Universidade Nove de Julho \\ mauriciolamano@uninove.br*
}

Article submitted in December/2015 and accepted in May/2016

DOI: $10.15628 /$ holos.2016.3819

\begin{abstract}
Environmental issues in urban areas have been increasingly discussed in the construction of smart and sustainable cities. Thus, public green spaces have become the focus of studies for bringing several contributions to the urban environment, as well as provide many ecosystem services. However, it is important to know how users of these green spaces perceive the environment around them, especially in the context of creating new parks in areas with intense human settlements. The aim of this study was to investigate the ecological knowledge of residents surrounding an urban green area in the east zone of São Paulo city, which became municipal park after the end of this study. The Municipal Park Jardim da Conquista (PMJC) is located in
\end{abstract}

an area considered one of the largest human settlements in Brazil and the world. 675 interviews were carried out with people living around the urban park in 2013. The profile of the supposed goers varies between 20 and 30 years, belonging predominantly to $C$ economic class and also with sporadic profile of visiting the park. The interviewed people related these green spaces with leisure and biodiversity conservation. In addition, residents attribute part of the care and preservation of the park to themselves. This work highlights the user profile of a new park in the city of São Paulo, as well as their knowledge of some ecological aspects of an urban park.

KEYWORDS: public spaces, green areas, Ethnoecology.

\section{CONHECIMENTO ECOLÓGICO SOBRE UNIDADES DE CONSERVAÇÃO NA ZONA LESTE DE SÃO PAULO, SP: IMPLICAÇÕES PARA SUSTENTABILIDADE EM ÁREA URBANA}

\section{RESUMO}

As questões ambientais em áreas urbanas têm sido cada vez mais discutidas no âmbito da construção de cidades inteligentes e sustentáveis. Assim, os espaços verdes públicos têm se tornado foco de estudos por diversas contribuições para o ambiente urbano, além de oferecem diversos benefícios ecossistêmicos. No entanto, torna-se importante saber como os usuários destes espaços verdes percebem o ambiente ao seu redor, especialmente num contexto de criação de novos parques em áreas com intensos assentamentos humanos. O objetivo deste trabalho foi investigar o conhecimento ecológico de residentes do entorno de uma área verde urbana na zona Leste de São Paulo, a qual se tornou parque municipal após o término deste estudo. O Parque Municipal Jardim da Conquista (PMJC) está localizado numa região considerada um dos maiores aglomerados humanos do Brasil e do mundo. Para tanto, foram realizadas 675 entrevistas com moradores do entorno do parque urbano no ano de 2013. A faixa etária dos frequentadores concentra-se entre 20 e 30 anos, com o predomínio da classe econômica C e com perfil de visitantes esporádicos no parque. A população entrevistada relacionou esses espaços verdes principalmente com momento de lazer e com a conservação da biodiversidade. Além disso, os moradores atribuem parte do cuidado e preservação do parque aos próprios frequentadores. Este trabalho destaca o perfil do usuário de um novo parque na cidade de São Paulo, bem como o seu conhecimento sobre alguns aspectos ecológicos de uma área verde urbana.

PALAVRAS-CHAVE: Espaços públicos, Áreas verdes, Etnoecologia. 


\section{INTRODUCTION}

The discussion on environmental problems in recent decades has become a topic widely discussed in urban spaces, which highlights issues in urban green areas in the defense of the environment due to the intense process of land use change occurred since the beginning of last century (Loboda \& De Angelis, 2005 Barros et al., 2015).

The urbanization process leads to changes in the organization of spaces, in the landscapes planning, in the channeling streams and also in the replacement of native vegetation by exotic species (Almada, 2010). Urban green areas have been highlighted as one of the key elements contributing to improve the quality of environment and life of urban population (Baumgarten, 2006; Silva \& Varga, 2010; Kardan et al, 2015), thus following the premises of the Working Group III of the Intergovernmental Panel on climate change (IPCC, 2007), which suggests that sustainable development is achieved through policies related to natural resource use, consumption patterns, quality of life and land use changes.

Municipal Secretariat of Vegetation and Environment of São Paulo City (MSVE/SP), as well as other Brazilian municipal secretariats, has the power to determine the areas to be effected as urban parks (SNUC, 2000), aiming to recover and integrate the urban landscape, reduce the levels of air pollution, reducing human negative impact on environment, improving microclimate and promoting outdoor recreation areas (SVMA, 2010). The first park created by the São Paulo's city hall was the Public Garden, currently known as Parque da Luz, dating from 1825 (Whately et al., 2008). Today, the São Paulo city has 109 parks, with 85 conventional parks, 18 linear parks and 6 Municipal Natural Parks (MNP). There are also two Environmental Protection Areas (APAs) and one Private Natural Heritage Reserve (PNHR) (SVMA, 2014).

In addition to the promotion of environmental services, urban parks can be used by the population in recreational and spiritual activities and to rest. Therefore, users are key elements in the setting of these green areas, and some of them use this space for their daily sports activities. This is reinforced by Costa et al. (2011), who mentioned that despite the possible benefits of creating urban squares and parks, those benefits will only be fully achieved if people take ownership and participate in these spaces. The parks tend to be underutilized, neglected and left out, becoming vulnerable and place of marginalization without involvement of the population.

According to Tuan (2012), people perceive and evaluate the natural environment in different ways, stating that two people do not see the same reality. Thus, it is important to know the cultural history to understand the environmental preference of a group.

In this context, perception and knowledge of population on ecological attributes of a park become crucial, since such information can be used in strategic planning and management improvements of these green areas, and contribute to sustainable municipal planning, in order to meet aspirations of population.

Considering the importance of the urban green areas studies, the present work tested a hypothesis that the regulars of a new municipal park of São Paulo East Zone have basic knowledge about ecological functions of an urban park and a degree of engagement in participatory park management, in case it was created by São Paulo Municipality. This study aims to evaluate the knowledge of residents surrounding a green area chosen for implementation of Parque Municipal 
Jardim da Conquista, based on some ecological attributes inherent to the urban forests and protected areas.

\section{METHODOLOGY}

\subsection{Field of Study}

This study was carried out with the population living in the vicinity of Parque Municipal Jardim da Conquista (PMJC), located in the eastern region of São Paulo, which is one of the 32 boroughs, as shown in Figure 1 (PMSP, 2014). The park is located in the São Mateus District that belongs to São Mateus borough, composed of three districts: São Mateus, São Rafael e Iguatemi. São Mateus district has an area of $12,830 \mathrm{~km}^{2}$, and a population that reaches 158,828 inhabitants (ANCHIETA, 2010). The park area is approximately 559,292 $\mathrm{m}^{2}$ (PMSP, 2014).

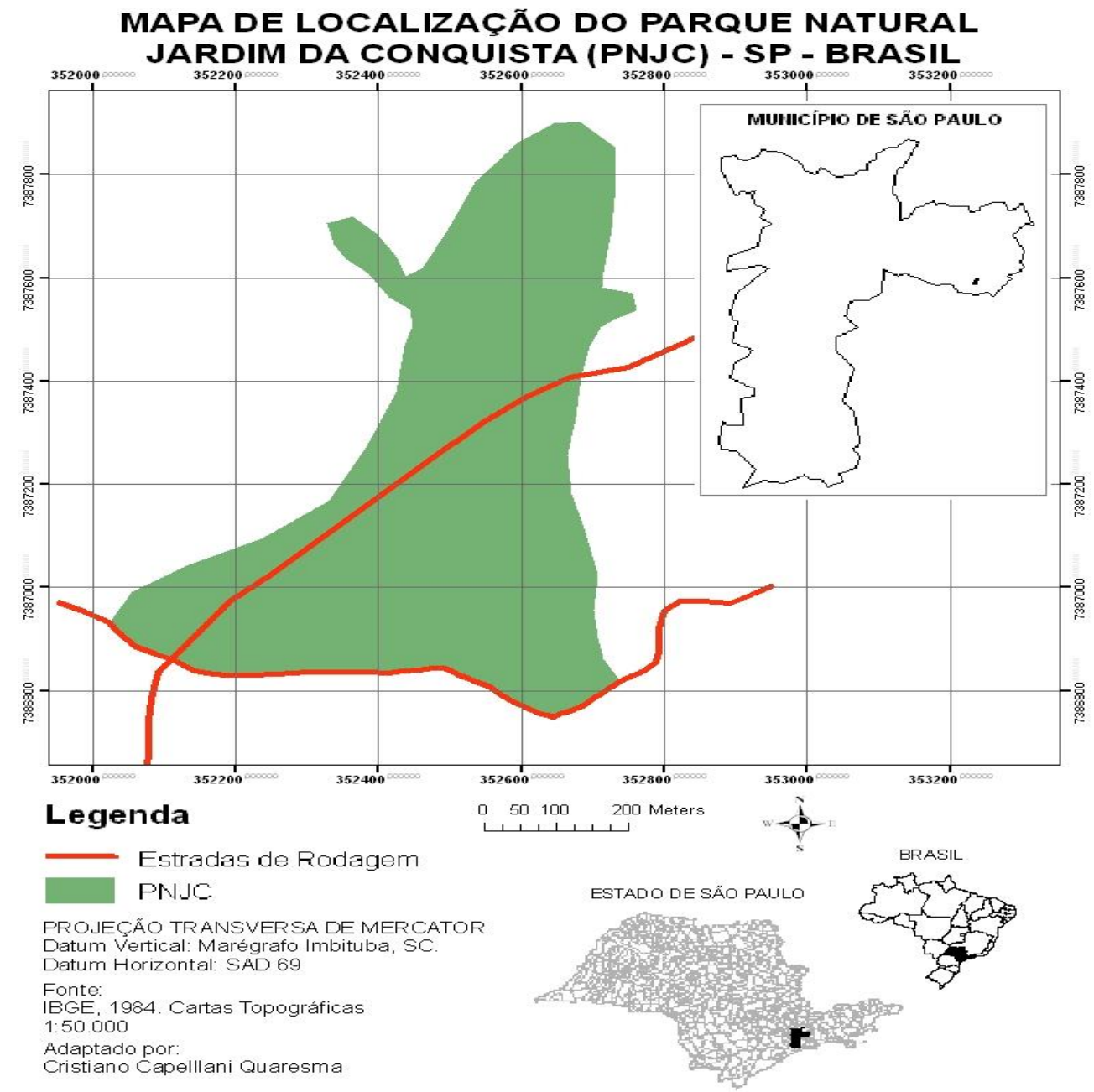

Figure 1: Localization of Parque Municipal Jardim da Conquista, exactly at São Mateus borough.

Currently, PMJC region is a free area located amidst the urban area of residential character and strongly anthropic activities (PMSP, 2014). However, it has extremely poor record for not having many homes and buildings because it was rubbish, waste, car debris and even bodies dump site (SVMA, 2004). The area where the new park will be effectively made is a partition for six 
districts, namely: Jardim da Conquista, Jardim Alto Paulistano, Vila Bela, Nova Conquista, Jardim Santo André e Jardim do Vale (PMSP, 2014).

The main feature of the park project is to preserve the headwaters of Córrego Caguaçu, an affluent of Rio Aricanduva, and riparian vegetation with native species. The park vegetation consists of Atlantic Forest in the early stages of succession, swamp, lawns, gardens, trees and recent anthropic field. In addition, the park offers infrastructure for leisure and fitness equipment.

\subsection{Research Description}

An exploratory research was carried out that, according to Gil (2002), provides a greater familiarity with the proposed problem, in order to make it more explicit. In this study, we sought to understand the perceptions of a group of residents in an area with implementation of a park, to understand what aspects are important for those potential regulars. It was conducted an initial contact with the individuals to be investigated (Santos, 1991) in order to understand possible reasons for certain behaviors (Révillion, 2003), or to explore which variables are involved in the decision to go to the green space that was being implemented. Thus, this type of research provided data collection on future regulars, aiming to understand how the population sees and might engage with the new protected area, since there is no research on perception of the population living near PMJC.

Data collection was conducted through interviews with residents who live around the area where the PMJC is going to be implemented. An adapted questionnaire of Cunha et al. (2007) was used. The limit to set the region was 100 meters from the park area bars. The respondents were 18 years old or older.

The interviews lasted 15 to 30 minutes, depending on availability and on volunteer interest, with door to door survey, consisting of a semi-structured questionnaire with open and closed questions (Marconi \& Lakatos 2002). Data collection was conducted from October 2011 to March 2012. For the volunteers with reading difficulties, the alternatives were read in the sequence they appear in the questionnaire. A freelist methodology was also used, which consists of asking respondents which items come to mind on a given question (Fraccaro et al., 2010).

\section{RESULTS AND DISCUSSIONS}

In the interviewed population ( $n=675$ ), $43 \%$ live in Jardim da Conquista, $22 \%$ live in Vila Bela, $17 \%$ live in Jardim Nova Conquista, $9 \%$ live in Jardim Santo André and $9 \%$ live in Jardim Paulistano Alto. Most respondents are female, amounting to $60 \%$. In this study, the age group that predominated was between 20 and 30 years (37\%) and the lowest proportion of respondents was people over 65 years (6\%), as shown in Figure $2 \mathrm{~A}$. A prominent factor is that $59 \%$ of the interviewed population belonged to socioeconomic C class, according to the classification of IBGE (2010). It is noteworthy that the socioeconomic class $A$ was underrepresented in this study, not getting enough responses to achieve a percentage point $(n=2)$. As regards the residence time, $25 \%$ of respondents had 20 years of residence in the place, but $21 \%$ had up to 5 years. As to origin, $90 \%$ of respondents were immigrants, and of these $93 \%$ were immigrants from other urban area.

In order to establish an indirect relationship between the new protected area and any life history attribute of each person who participated in the interview, it was asked each respondent to say any word that came to mind when hearing the word "park" (Fig. 2B). The word "leisure" was 
the most related with $58 \%$ of recurrence. The data collected in relation to cultural activities had the lowest percentage (3\%). These results corroborate the data from studies carried out in public squares (Fermino et al., 2012; Rego et al., 2011 Rocha \& Abjaud 2012.), which is where the population seeks leisure, sometimes directed to children (Szymczak et al., 2012).

a) Age group

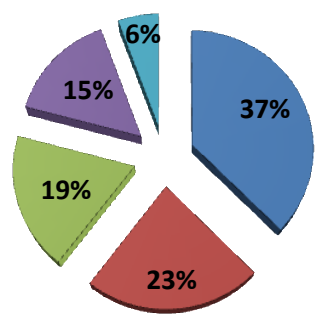

$\square 20$ a 30

$\square 41150$

$\square 51$ а 60

$\square 61 \mathrm{ou}+$

b) Frelist "Park"

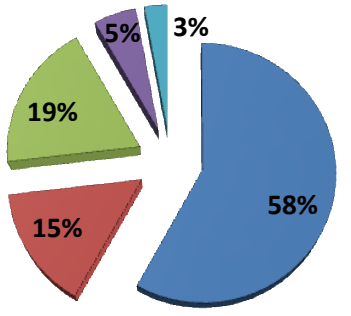

$\square$ Leisure $\square$ Sports $\square$ Environment $\square$ Security $\square$ Cultural

Figure 2: Representation of answers obtained in Parque Municipal Jardim da Conquista area. In "a", the age group. In " $b$ ", the answers from freelist.

Visitation to parks was reported by $74 \%$ of respondents (Figure $3 \mathrm{~A}$ ), the majority (79\%) goes to these natural environments sporadically. Among the respondents, the majority (81\%) frequents parks with family, $18 \%$ visit with friends or colleagues. Júnior (2004) reported that $64 \%$ of respondents said they have visited parks in Belém, Pará State, indicating this routine as inherent to urban citizen. Teramussi (2008) reported the environmental perception of regulars in Parque Ecológico do Tietê, SP, and found that $72.5 \%$ of users usually visited urban parks.

For Zimmermann (2006), in his study conducted on visitation to Brazilian natural parks, less than half $(47 \%)$ of respondents have visited national parks. Whately et al. (2008) showed the monthly frequency of users highlighting the parks as places of rest and recreation in a study of urban parks in São Paulo, SP.

For the population of this study, the main reason for attending the parks is leisure $(83 \%$ of respondents), for $96 \%$ of respondents, the park contributes to a better quality of life. The remaining $4 \%$ considered the environment indifferent for daily, weekly and monthly routines. Costa et al. (2011) also found the leisure as the main reason for visits to an urban park. Júnior (2004) showed by means of a study on bird conservation in urban areas that $24 \%$ of respondents also seek urban green areas for the purpose of leisure. However, some studies have found other results, as Zimmermann (2006), for whom which most of the respondents said that the main purpose to visit a park was the contemplation of natural resources (34.5\%). It is important to note that the type of park can arouse special interest in users, since parks (natural) are provided with natural vegetation, and some city parks are made up of sports courts and recreational areas. 


\section{a) Park visitation frequency}

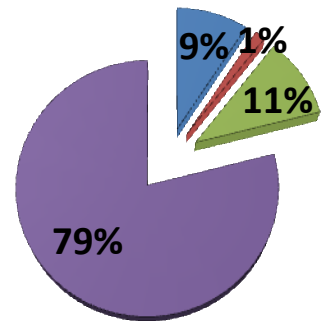

$\square$ Weekly $\square$ Biweekly $\square$ Monthly $\square$ Sporadic

\section{b) Socio-ecological function of a park}

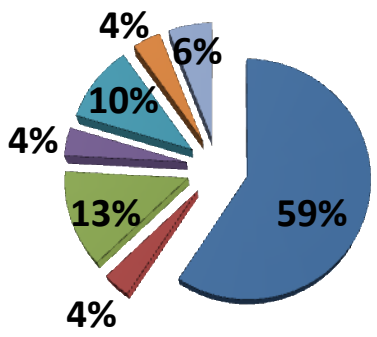

$\square$ Leisure
$\square$ Rest $\begin{array}{ll}\square \text { Sports } & \square \text { Conservation } \square \text { Valorization } \\ \square \text { Cleaning } & \square \text { Do not know }\end{array}$

Figure 3: Representation of the responses obtained in Parque Municipal Jardim da Conquista area. In "a", the answers regarding the park visitation frequency. In " $b$ ", the graph referring to the function of a park.

When making the statement "it is fundamental the community involvement in the care and preservation of the park", it was requested a score between one and ten. Most respondents (94\%) assigned a score equal to or greater than six points, which features a probable involvement of future users of Parque Municipal Jardim da Conquista with participatory management of this initiative. Regarding the role of the parks, 59\% associated it with recreational activities, conservation (13\%) and rest (10\%), as shown in Figure 4 a. When asked about the most common animals in parks, $40 \%$ of respondents answered that the birds are the most common, followed by mammals (36\%), fish (13\%), reptiles (7\%), amphibians $(3 \%)$, and invertebrates are perceived by only $1 \%$ of respondents, as shown in Figure $4 \mathrm{~b}$. For $47 \%$ of respondents, the importance of these animals in a park is associated with conservation of natural ecosystems.

a) Park structure

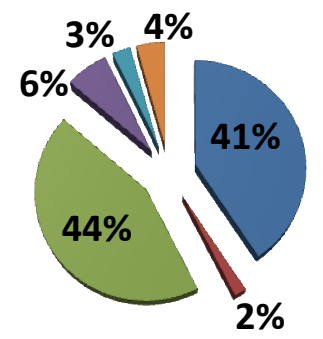

b) Park fauna

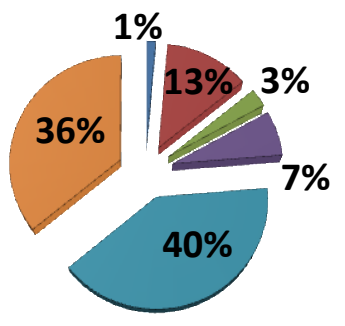

$\square$ Invertebrates $\square$ Fish

$\square$ Reptiles

$\square$ Birds

Amphibian

Mammals

Figure 4: Representation of the responses obtained in Parque Municipal Jardim da Conquista area. In "a", the answers regarding park structure. In " $b$ ", the graph refers to the fauna found in an urban park.

Among the respondents, $57 \%$ reported interaction with animals in some way, and of these, $47 \%$ do it through observation. The other replied that the interaction occurs mainly through photographs, games and food (Figure 5a). These results make a great analogy to ecosystem services that promote green areas in urban ecosystems. Costanza et al. (1997) and de Groot (2002) highlight the importance of natural ecosystems in ecological processes and value the various services that nature provides to humans, among which we can highlight the dispersal and pollination of plant species, meat supply to some human populations and recreational interaction. 
On the other hand, the relevance of plants was perceived in all respondents. Some people related the importance of plants in parks to conservation (31\%), absorption of pollutants (29\%), ornamentation (28\%) and shadow (7\%) (Figure 5b).

Interaction with park fauna
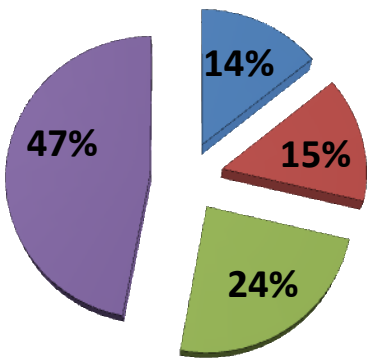

$\square$ Feeding

$\square$ Photographing
Socio-ecological importance of plants for a park

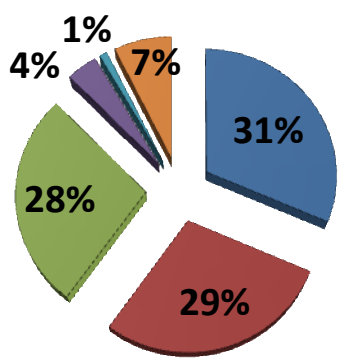

$\square$ Minimizes atm pollution $\square$ Ornamnts

口Medicinal $\square$ Shadow

Figure 5: Representation of the responses obtained in Parque Municipal Jardim da Conquista area. In "a", the results obtained by question on respondent interaction with animals in a park. In " $b$ ", the result obtained by question on importance of plants to a park.

When asked about the importance of plants for the city and not just for a park, the main reason was conservation (72\%) and ornaments (16\%), as shown in Figure 6A. Enlarging the scale, users were asked about the importance of plants to nature as a whole, and $43 \%$ of respondents highlighted the relation with air pollutants (Figure 6B), thus reducing one of the waste from uncontrolled urbanization. Respondents mainly knew fruiting plants (39\%), 81\% of respondents said that if allowed, would make use of public park plants. For the respondents, the most frequent use of plants would be for medicinal purposes (40\%).

Socio-ecological importance of plants for urban ecosystem

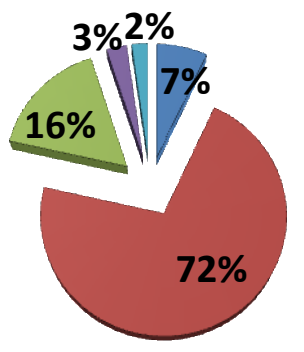

$\square$ Do not know $\square$ Conservation $\square$ Ornaments $\square$ Shadow $\square$ Medicinal

\section{Socio-ecological importance of plants for nonurban ecosystem}

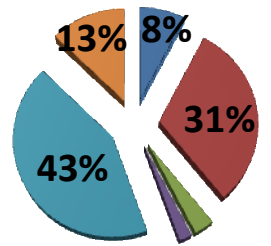

$2 \% 3 \%$

口Ornaments

口Shadow

$\square$ Conservation
$\square$ Minimizes atm pollution

$\square$ Medicine DDo not know

Figure 6 Representation of the responses obtained in Parque Municipal Jardim da Conquista area. In "a", the result obtained by question about the importance of plants for an urban ecosystem. In " $b$ ", the result obtained by question about the importance of plants to a non-urban ecosystem.

Regarding the main structural needs of a park, the interviewed population elected as a priority the dumps (46\%), lighting (20\%), lawn (17\%), ornamentation (10\%) and paving (7\%), as Figure $7 \mathrm{a}$. When asked about the responsibilities and care of a park, $90 \%$ of respondents said that the main responsibility lies with the Government and the local community. Most respondents (61\%) reported interest and willingness to participate in meetings to discuss the operation of a park and participatory management. Among these respondents, 53\% answered that participation could be monthly, weekly (31\%) and every fifteen days (16\%) (Figure 7B). Carvalho, Nascimento 
and Ferreira (2010) also obtained very similar results in an ethnoecological article, considering $86 \%$ answered that the main responsibility for the maintenance and care of the park lies with the Government and the local community. Teramussi (2008) obtained a further result, ie, $75 \%$ of respondents relate responsibility to the population that frequents the place. This is the community vision when they share responsibility for public green areas.

\section{a) Priorities of the structure/equipment of a park}

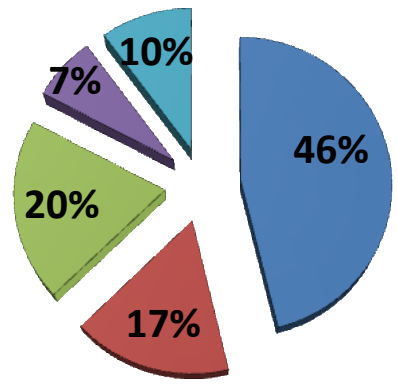

$\square$ Lixeira $\square$ Lawn $\square$ Lighting $\square$ Paving $\square$ Ornamentation

\section{b) Frquency of visit to a park}

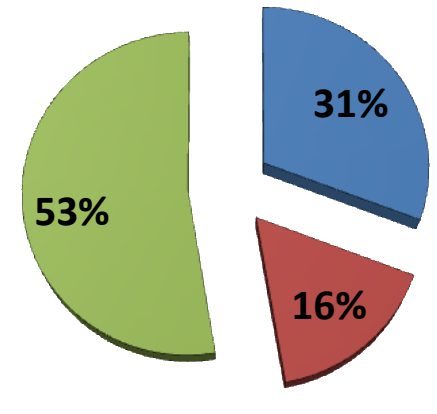

$\square$ Weekly $\square$ Biweekly $\square$ Monthly

Figure 7: Representation of the responses obtained in Parque Municipal Jardim da Conquista area. In "a", the result obtained by the question on main structures and equipment a park should contain. In " $b$ ", the result about the likely frequency of visits to a park near their own homes.

According to Macedo (2008), it is consolidated in the environmental sphere the need to involve individuals directly or indirectly linked to the process of management of green areas and make them partners in sustainable development projects. In his study, the author found that when a park has community participation since its beginning, anthropogenic pressures are minimized. This idea is supported by Son (2009), who reported that $99.5 \%$ of respondents said that direct community participation in key decisions in city planning is required. Whately et al. (2008) found that $71 \%$ of respondents in his study were willing to work with the participatory management of urban park.

Whereas the parks can make the day of those who live around it better, whether by offering recreational and sports areas or contact with nature, most (96\%) of respondents said that an urban park is important for the best quality of life. This idea is supported by Son (2009), which reports that $99.5 \%$ of respondents said that direct community participation in key decisions in city planning is required. Whately et al. (2008) found that $71 \%$ of respondents in their study were willing to work with the participatory management of urban park.

Whereas the parks can make the day of those who live around it better, whether by offering recreational and sports areas or contact with nature, most $(96 \%)$ of respondents said that an urban park is important for the best quality of life. Similar results were also presented by Ribeiro (2010) and Teramussi (2008) in articles on environmental perception carried out with communities surrounding an urban forest. Pimentel (2008) pointed out in his work on urban biodiversity that knowledge of a given population on urban parks and forests is an important conservation component, and this should be part of the management of urban green areas.

The area of PMJC is part of an expropriation for environmental compensation from a state work (extension of Avenida Jacu Pêssego, developed by the Companhia de Desenvolvimento Rodoviário S/A - DERSA/SP), linking Guarulhos to Mauá, passing through São Paulo (CMSP, 2009). 
Creating parks is permeated with meanings and values that gradually are known and assimilated by the society (Rodrigues, 2009), even though in many cases the relationship between population and green area can be disturbed by small invader groups of green areas indicated as conservation units (Arce et al., 2014). Thus, it is evident the need for public policy projects that include urban and environmental development, in order to minimize potential conflicts.

\section{FINAL CONSIDERATIONS}

With this paper, it was possible to draw a profile of residents of the vicinity of the new Parque Municipal Jardim da Conquista. The data indicate that the regulars are mostly female, between 20 and 30 years of age, residents of Jardim da Conquista district, belonging to the class $C$, with expectation of sporadic visit. When thinking of park, the surrounding population linked the word with leisure, which is identified as the main reason for visiting a park, which is accompanied by the word family. In addition, people interviewed attributed part of the care and preservation of the park to the community.

In relation to living beings, the animals most often cited by users of PMJC as belonging to the green area were the birds. Respondents say plants are important for a park, mainly for the reason of "conservation". These answers relate to the services provided by these living beings, especially with regard to the maintenance of urban biodiversity, nutrient cycling and climate maintenance. The main plants cited by respondents were fruit plants, which are related to recreational and eating habits brought by their respective personal experiences with nature. This work also aims to contribute to future strategic plans of creation, maintenance and management of urban parks, particularly those that are implemented in areas with high population density, such as São Paulo East Zone.

\section{REFERENCES}

1. Almada, E. D. Sociobiodiversidade Urbana: por uma etnoecologia das cidades. In: V. A. Silva, A. L. Almeida, \& Albuquerque, U. P.. Etnobiologia e Etnoecologia: Pessoas \& Natureza na América Latina (pp. 39-63). Recife: Nuppea, 2010.

2. Anchieta, A.C. B. J. (2010) Guia Cultural e Turístico da Zona Leste de São Paulo, 2010. Secretaria de Estado da Cultura, Governo do Estado de São Paulo.

3. Arce, P. A.; Pendloski, C. J. S.; Oliveira, R. B.; Gallardo, A. L. C. F.; Ruiz, M. S. Conflitos socioambientais em unidades de conservação em áreas urbanas: o caso do parque Tizo em São Paulo. Holos, v.1, p. 71-85, 2014.

4. Barros, L. H. V., V.; Silva, P.; Alves, G. A.; Pinheiro, L. G.; Nascimento, I.; Dias, P. K. L.; Oliveira, R. F. A.; Santana, Oliveira, W. A.; C. S. C.; Medeiros,C. S. C.; Gomes, B. S. F. F. Diagnóstico das áreas verdes públicas do bairro Potengi, Natal - RN. Holos, v. 5, p. 130-141, 2015.

5. Baumgarten, H. A administração das áreas verdes públicas e espaços livres nas cidades alemãs. Revista da Sociedade Brasileira de Arborização Urbana, Piracicaba -SP, v. 1, n. 1, 2006.

6. Carniello, M. A. Estudo etnobotânico nas comunidades de Porto Limão, Porto Alambrado e Campo Alegre, na fronteira Brasil-Bolívia, Mato Grosso, Brasil. Universidade estadual paulista "Julio de Mesquita Filho". Instituto de biociências - Rio Claro programa de pós-graduação em 
Ciências Biológicas / Biologia Vegetal. Rio Claro, 2007.

7. CAMARA MUNICIPAL DE SÃO PAULO. CMSP. Disponível em (http://www2.camara.sp.gov.br/ projetos/00/00/02/KK/000002KK4.PDF). Visitado em 10/09/2009.

8. Costa, R. G. S.; Benachio, M. V.; Borges, A. A.S.; Colesanti, M. T. M. (2011) Uso, afetividade e percepção: Um estudo da satisfação dos frequentadores do Parque do Sabiá em Uberlândia MG. Revista de Geografia (UFPE) V. 28, No. 1. Uberlândia.

9. Costa, R. G. S. \& Colesanti, M. M. (2011). A contribuição da percepção ambiental nos estudos das áreas verdes - Curitiba. $R A^{\prime} E$ GA, 22, 238-251.

10. Cunha, H. F.; Vale, M. S.; Junior, C. A. S.; Campos, R. F.; Carlos, L. O. Conhecimento empírico dos moradores da comunidade do entorno do Parque Municipal da Cachoeirinha (Iporá Goiás). Portal de Revistas Científicas em Ciências da Saúde. Iporá, 2007.

11. Fermino, R. C., Reis, R. S. \& Cassou, A. C. (2012). Fatores individuais e ambientais associados ao uso de parques e praças por adultos de Curitiba-PR, Brasil. Rev. Bras. Cineantropom Desempenho Hum, 4(4), 377-389.

12. Ferreira, M.L.; Carvalho, A.R.; Nascimento, A.P.B. (2010) A Opinião Dos Moradores Do Entorno Da Praça Manuel Rodrigues Sécio (São Paulo/Sp) Sobre O Seu Estado De Conservação: Uma Ferramenta Para O Plano De Educação Ambiental. X Encontro Latino Americano de PósGraduação, São José dos Campos, SP.

13. Filho, J. T. O. participação popular no planejamento urbano: A experiência do plano diretor de Porto Alegre. Universidade Federal do Rio Grande do Sul, Faculdade de Arquitetura, Programa de Pós Graduação em Planejamento Urbano e Regional. Porto Alegre, 2009.

14. Fraccaro, L. C. Z; Silva, M. P.; Molina, S. M. G. (2010) A percepção ambiental sob a ótica humana: o estudo da população rural do município e Ipeúna, SP. São Paulo, 2010. Anais do V ENANPPAS - Florianópolis: Encontro Nacional da ANPPAS.

15. Gil, A. C. (2002). Como elaborar projetos de pesquisa. São Paulo, 5, 61.

16. Junior, P. C. B. N. Parque ambiental de Belém: Um estudo da conservação da fauna silvestre local e a interação desta atividade com a comunidade do entorno. Revista Científica da UFPA, vol.4. Belém, 2004.

17. Loboda, C. R. \& De Angelis, B. L. D. (2005). Áreas verdes urbanas: conceitos, usos e funções. Ambiência, 1(1), 125-139.

18. Macêdo, J. A. C. Avaliação da gestão participativa dos parques estaduais da Bahia. Dissertação de Mestrado, Centro de Desenvolvimento Sustentável, Universidade de Brasília. Brasília, 2008.

19. Magalhães, A. F. A.; Vasconcellos, M. K. (2007) Fauna silvestre: Quem são e onde vivem os animais na metrópole paulistana. São Paulo.

20. Marconi, M.A.; Lakatos, E.M. (2002) Técnicas de Pesquisa: planejamento e execução de pesquisas, amostragens e técnicas de pesquisas, elaboração, análise e interpretação de dados. São Paulo: Atlas.

21. MF. MINISTÉRIO DA FAZENDA, 2010. Disponível em (www.mf.gov.br). Acesso em 28/08/11, ás $18 \mathrm{~h} 30 \mathrm{~min}$.

22. BRASIL. MINISTÉRIO DO MEIO AMBIENTE (MMA), 2011. Disponível no endereço (www.mma.gov.br). Acesso em 24/03/2011, ás 15h40min. 
23. PIMENTEL, D. S. (2008) Os "parques de papel" e o papel social dos parques, Tese apresentada para obtenção do título de Doutor em Recursos Florestais. Piracicaba.

24. PMSP. PREFEITURA DO MUNICÍPIO DE SÃO PAULO - Secretaria Do Verde E Meio Ambiente SVMA. Disponível em: <http.prefeitura.sp.gov.br/cidade/secretarias/meio_ambiente/par ques/região_leste/index.php?> Acesso em 23/04/2014.

25. PREFEITURA DO MUNICÍPIO DE SÃO PAULO - PMSP - Secretaria Do Verde E Meio Ambiente SVMA. Carta da Terra. São Paulo, 2010.

26. PMSP. PREFEITURA DO MUNICÍPIO DE SÃO PAULO - SECRETARIA DO VERDE E MEIO AMBIENTE SVMA. (2004) Atlas Ambiental do Município de São Paulo, o verde, o território o ser humano. São Paulo.

27. PMSP. PREFEITURA DO MUNICÍPIO DE SÃO PAULO - SECRETARIA DO VERDE E MEIO AMBIENTE SVMA. (2014) Guia de Parques Municipais de São Paulo, IV Edição Atualizada e Revisada. Disponível em: http://issuu.com/svmasp/docs/guia_dos_parques, Acesso em 27/10/2015.

28. Ribeiro, A. P. (2010) A análise da percepção sócio-ambiental dos moradores do entorno quanto à criação do Parque Morro São Pedro. Universidade Federal do Rio Grande do Sul, Instituto de Geociências, Departamento de Geografia. Porto Alegre.

29. Rocha, E. A. \& Abjaud, T. T. (2012). A metropolização de belo horizonte e sua relação com as áreas verdes e o turismo: Parque das Mangabeiras x Praça Sete. Revista Acadêmica, VII(3), 6385.

30. Rodrigues, C.G. O. (2009) O uso público nos parques nacionais: A relação entre as esferas pública e privada na apropriação da biodiversidade. Tese de Doutorado submetida ao Centro de Desenvolvimento Sustentável da Universidade de Brasília, como parte dos requisitos necessários para a obtenção do Grau de Doutor em Desenvolvimento Sustentável, área de concentração em Política e Gestão Ambiental. Brasília.

31. Santos, J.V.T. (1991) A construção da viagem inversa. Cadernos de Sociologia, ensaio sobre a investigação nas ciências sociais, Porto Alegre, v. 3, n. 3, p. 55-88.

32. Silva, C. F. R.; Vargas, M.A.M. (2010) Sustentabilidade Urbana: Raízes, Conceitos e Representações. Scientia Plena, v. 6, n. 3.

33. SNUC - SISTEMA NACIONAL DE UNIDADES DE CONSERVAÇÃO. Lei n. 9.985 de 18/07/2000.

34. Teramussi, T. M. Percepção ambiental de estudantes sobre o Parque Ecológico do Tietê; São Paulo - SP. Universidade de São Paulo Programa de Pós-graduação em Ciências Ambiental PROCAM. São Paulo, 2008.

35. Révillion, A.S.P. (2003) A Utilização de Pesquisas Exploratórias na Área de Marketing. RIMAR Revista Interdisciplinar de Marketing, v.2, n.2, p. 21-37

36. Tuan, Y. F. (2012). Topofilia: um estudo da percepção, atitudes e valores do meio ambiente. São Paulo: Eduel.

37. Whately, M.; Santoro, P. F.; Gonçalves, B. C.; Gonzato, A. M. (2008) Parques Urbanos Municipais de São Paulo, Subsídio para gestão - SP.

38. Zimmermann, A. (2006) Visitação nos parques nacionais brasileiros: Um estudo à luz das experiências do Equador e da Argentina. Dissertação de Mestrado submetida ao Centro de Desenvolvimento Sustentável da Universidade de Brasília, como parte dos requisitos 
necessários para a obtenção do Grau de Mestre em Desenvolvimento Sustentável, área de concentração Política e Gestão Ambiental, opção Acadêmica. Brasília. 